\title{
A CALL FOR A DIFFERENCE IN TREATMENT BETWEEN CHILD AND ADULT OFFENDERS IN THE SOUTH AFRICAN PAROLE SYSTEM: AN INTERNATIONAL LAW PERSPECTIVE
}

by I Gueorguieva*

\section{Introduction}

Internationally, parole is recognised and accepted ${ }^{1}$ as a means of the conditional release of a sentenced offender from a correctional centre into the community, before the expiration of the judicially imposed sentence of such offender. ${ }^{2}$ The functions of the placement on parole of the offender, which associate with the offender, include the rehabilitation of the offender and his reintegration into the community, ${ }^{3}$ as well as his restitution (e.g. in the form of symbolic restitution or community service). ${ }^{4}$ In Correctional Services authorities, parole acts occur to relieve prison overcrowding, encourage good behaviour within correctional facilities and to save costs related to imprisonment without negating the benefits of continued supervision and control. ${ }^{5}$

In South Africa, parole is predominantly governed by the Correctional Services Act 111 of 1998 (as amended) or, more particularly chapter IV (dealing with sentenced offenders), chapter VI (community corrections) and chapter VII (release from correctional centre and placement under correctional supervision and on day parole and parole). The provisions of chapter IV came into operation on 31 July 2004, whilst those of chapters V and VI came into operation on 1 October $2004 .{ }^{6}$ In addition, the provisions of the Correctional Services B-Order, Sub-Order 1, Incarceration Administration (hereinafter referred to as the Parole Manual) go a long way in clarifying and expanding on provisions in the Correctional Services Act, as well as indicating the practice and policy of the various

* Ina Gueorguieva, final year LLB student, University of Pretoria.

CML Louw 'The Parole Process from a South African Perspective' unpublished LLM thesis, University of South Africa, 2008375.

2 CH Cilliers 'New horizons for parole application in South Africa' (2006) 19(3) Acta Criminologica $i$.

Louw (n 1 above).

Louw (n 1 above) 38-39.

Louw (n 1 above) 40-42.

Proclamation R38, 2004 published in Government Gazette 26626, 30 July 2004. 
functionaries involved in the parole system. Section 28(1)(g) of the Constitution of the Republic of South Africa, 1996 (Constitution), on the other hand, provides that a child has the right not to be detained except as a measure of last resort and then only for the shortest appropriate period. Section 28(2) further provides that a child's best interests are of paramount importance in every matter concerning the child.

The question can then be raised: what effect do the above provisions have on the parole consideration of child offenders? Additionally, one can ask whether there is sufficient justification for a difference in parole treatment between child and adult offenders.

In order to answer the above questions, and to determine the additional issue of whether the South African parole system succeeds in measuring up to both international standards as well as its own constitutionally and legislatively entrenched aims, the provisions of several international instruments will be consulted and evaluated. This is desirable in view of the fact that the Constitution clearly provides in section 39(1)(b) that when interpreting the Bill of Rights a court, tribunal, or forum must, inter alia, consider international law. In other words, international norms and standards may have persuasive or even decisive value in court.

Before this is done, however, it will first be determined whether there is in fact a difference in treatment between children and adults within the South African parole system.

It should be noted at this stage that the Department of Correctional Services employee figures for 2005 indicated that there was one social worker available per 595 offenders, and 1 psychologist per 11223 offenders. ${ }^{7}$ This factor (combined with prison overcrowding) diminishes efforts to rehabilitate offenders. ${ }^{8}$ These professional persons are involved in assessing offenders, monitoring their mental development etc. ${ }^{9}$ They also provide insight to the Case Management Committee (CMC), which is responsible for compiling and submitting offender reports to the Correctional Supervision and Parole Board (CSPB). These reports inevitably influence the Board's decision as to whether or not an offender should be placed on parole. In other words, a shortage of psychologists and social workers diminishes the powers of the CMC, (and thus the CSPB and other functionaries) to properly consider an offender for parole as all the necessary information may not be before such authorities. 


\section{Differences in treatment between adults and children in the South African parole system}

The youth of an offender, at common law, has always been regarded as a mitigating factor in sentencing. ${ }^{10}$ There is also support for the proposition that age is a factor in parole placement consideration; Girdini has stated that '[s]tatistics have shown that age at the time of the first arrest have some bearing on parole success.'11

It can then be argued that a child offender could receive a double benefit, in that his youth is considered both at the sentencing phase and at the parole hearing. The age of a young offender, however, is not stated as a definite factor to be taken into consideration either in terms of the Parole Manual or in terms of legislation. The only indication that the young offender's age may be a factor is contained in the independent research undertaken by Louw and in Giardini's statement above. ${ }^{12}$ It is uncertain, however, whether the age factor in Louw's research is related to young age at the time of commission of the offence or to advanced age at the time of the parole hearing. (i.e. a life-sentenced offender who has reached the age of 65 may be placed on parole if he or she has already served 15 years of his or her sentence). ${ }^{13}$

It appears that the only concrete example of an age benefit coming into consideration at the parole hearing applies to the advanced age offenders mentioned above, as this is specifically provided for in legislation. ${ }^{14}$ Apart from that, adults, to whom that provision does not apply, and children are seemingly treated the same (despite the hypothetical argument canvassed above). The question can then be posed as to whether such a difference in treatment is desirable. This question will be answered with reference to international law provisions that influence the application of sentencing and parole, which are discussed below. In the meantime, it may be added that the 'discount' afforded to advanced age offenders makes little practical sense. The effect thereof is that someone who commits a life-sentence-worthy offence when he or she is 50 may only have to serve 15 years of a life sentence in prison. While, for example, a 17 -year-old may still have to serve 25 years before being considered for placement on parole (as this is the general non-parole period applicable to life-sentenced offenders). ${ }^{15}$ If one focuses on the age at the time of commission of the offence, it is questionable why a person

Director of Public Prosecutions, KZN v P 20061 All SA 446 (SCA) 451.

As referred to by GI Giardini The parole process (1959) 133 - 134.

Louw (n 1 above) 144.

Correctional Services Act 111 of $1998 \mathrm{sec}$ 73(6)(b)(iv).

As above.

As above. 
committing an offence at the age of 50 should benefit from special early release provisions while a 17-year-old offender should not.

\section{International provisions influencing sentencing and parole application}

At the outset, it may be noted that children in conflict with the law are dealt with by four main international instruments. ${ }^{16}$ These are the United Nations Convention on the Rights of the Child (CRC), ${ }^{17}$ the UN Guidelines for the Prevention of Juvenile Delinquency (Riyadh guidelines), ${ }^{18}$ the UN Standard Minimum Rules for the Administration of Juvenile Justice (Beijing Rules), ${ }^{19}$ and the UN Rules for the Protection of Juveniles Deprived of their Liberty (JDLs). ${ }^{20}$ Only the CRC is binding on South Africa as the South African parliament ratified it on 16 June 1995. None of the other instruments have been incorporated into our legislation. It should be noted, however, that law-making treaties might offer evidence of a widespread customary rule, in which case they could provide a basis for a legal obligation under customary international law that will be binding on nonsignatory states. 21

As already mentioned, the South African Bill of Rights provides, in section $28(1)(\mathrm{g})$, that every child has the right not to be detained except as a measure of last resort and only for the shortest appropriate period. In addition to that, section 28(2) significantly provides that a child's best interests be of paramount importance in every matter concerning the child. The standard of looking at what the child's best interest is has, in fact, often been described as a golden thread that runs through the whole fabric of the South African law relating to children. 22

The above provisions resonate clearly with international law provisions. For example, article 3 of the CRC also provides that the best interests of the child shall be a primary consideration in all actions concerning children. Article $37(\mathrm{~b})$ states that the arrest,

16 Brandt v S 2004 JOL 13262 (SCA) para 16.

17 United Nations Convention on the Rights of the Child, adopted by the UN General Assembly on 20 November 1989, Resolution 44/25.

18 United Nations Guidelines for the Prevention of Juvenile Delinquency, adopted by the UN General Assembly on 14 December 1990, Resolution 45/112.

19 United Nations Standard Minimum Rules for the Administration of Juvenile Justice, adopted by the UN General Assembly on 29 November 1985, Resolution 45/113.

20 United Nations Rules for the Protection of Juveniles Deprived of their Liberty, adopted by the UN General Assembly on 14 December 1990, Resolution 45/113. Also known as 'the JDL's'.

21 J Dugard International Law: A South African perspective (2005) 28.

22 B Bekink \& M Bekink 'Defining the standard of the best interest of the child' (2004) 1 De Jure 21. 
detention or imprisonment of a child shall be in conformity with the law and shall be used only as a measure of last resort and for the shortest appropriate period of time. Similarly, article 17(1)(b) of the Beijing Rules provides that restrictions on the personal liberty of the juvenile shall be imposed only after careful consideration and shall be limited to the possible minimum. Article 19(1) of the Rules adds that the placement of a juvenile in an institution shall always be a disposition of last resort and for the minimum necessary period.

It is perhaps important to point out the reason for the special protection of children and the reason why their best interests should form a primary consideration in the administration of juvenile justice. It has been stated that children differ from adults in their physical and psychological development as well as their emotional and educational needs. ${ }^{23}$ These differences, amongst others, constitute a basis for the lesser culpability (culpability here relates to blameworthiness, and thus involves the element of fault) of children in conflict with the law and justify a separate juvenile justice system and a different treatment for children. ${ }^{24}$ Preference should thus be given to aims such as rehabilitation and reintegration into the community. ${ }^{25}$ The Beijing Rules recognise this by providing, in article 2(2)(a), that a juvenile is a child or young person who, under the respective legal systems, may be dealt with regarding an offence in a manner that is different from an adult. Liefaard states that it is defensible to call for terms that are much shorter than those regarding adults at every stage. ${ }^{26}$

In returning to the discussion, it must be identified that international law provisions seem to go materially further than those of domestic law do. Article 3(3) of the Beijing Rules provides that efforts shall be made to extend the principles embodied in the Rules to young adult offenders. Furthermore, the commentary on article 17(1)(b) mentions that whereas in adult cases, and possibly also in cases of severe offences by juveniles, just desert and retributive sanctions might be considered to have some merit; in juvenile cases such considerations should always be outweighed by the interests of safeguarding the well being and future of the young person.

The above seems to tentatively imply that it is not only the best interests of the child that are worthy of protection, but that that child's future development as an adult is also of concern. It recognises that children under the age of 18 should not be viewed as existing in

23 UN Committee on the Rights of the Child (25 April 2007) General Comment 10: Children's rights in juvenile justicjustice, UN CRC (25 April 2007), UN Doc CRC/C/ GC/10para 10.

24 As above.

25 As above.

26 T Liefaard Deprivation of Liberty of Children in Light of International Human Rights Law and Standards (2008) 207. 
a vacuum. The serving of a sentence is a process, and particularly for children sentenced to life imprisonment, a particularly long one. Many children, who are sentenced for offences that they commit as children, remain in corrective facilities long past the age of adulthood.

In view of the above, it is my submission that the aims of childoffender-specific rehabilitation should not be abandoned upon the reaching of 18 years of age. It is the age at commission of the offence, which should be decisive upon continued treatment after reaching the age of 18. In other words, a child offender upon reaching the age of 18 should not suddenly be subject to the same rehabilitative programmes applying to adult offenders but, in view of their earlier separation from adult offenders and their consequently differing developmental needs, their age at the time of commission of the offence should continue to be taken into account. The commentary on article 19(1) of the Beijing Rules lends support to this argument. It states that:

Rule 19 aims at restricting institutionalisation in two regards: in quantity ('last resort') and in time ('minimum necessary period'). Rule 19 reflects one of the basic guiding principles of resolution 4 of the Sixth United Nations Congress: a juvenile offender should not be incarcerated unless there is no other appropriate response. The rule, therefore, makes the appeal that if a juvenile must be institutionalised, the loss of liberty should be restricted to the least possible degree, with special institutional arrangements for confinement and bearing in mind the differences in kinds of offenders, offences and institutions.

This argument can be supported by analogy with reference to another instance where an adult can benefit from provisions aimed specifically at children, that is, where a person who committed an offence as a child is only sentenced after he has turned 18. In this instance, Liefaard explains, ${ }^{27}$ (article 40 of the CRC provides that state parties recognise the right of every child alleged as, accused of, or recognised as having infringed the penal law to be treated in a manner consistent with the promotion of the child's sense of dignity and worth, which reinforces the child's respect for the human rights and fundamental freedoms of others and which takes into account the child's age and the desirability of promoting the child's reintegration and the child's assuming a constructive role in society) is still applicable to such offender in accordance with what he refers to as the 'crime date criterion' and that consequently he is also entitled to treatment in accordance with article 37 of the CRC (placement in a child facility). He states that this criterion 'is directly related to the ratio behind and legal foundation of a juvenile justice system, which aims at responding to the child's behaviour as a human being who is 
less culpable'. Clearly, reaching the age of 18 does not completely deprive persons who committed offences as children from benefiting (in some way) from the applicability of provisions aimed at such children in particular. Alternatively, it can be stated that, for a child offender who turns 18 while still under the control of corrections, some benefits relating to his age at the time of commission of offence, remain intact.

Coming back to the criterion of institutionalisation for the minimum amount of time, article 28(1) of the Beijing Rules must also be mentioned. It states that conditional release shall be used to the greatest possible extent and shall be granted at the earliest possible time. This can be read together with the further comment under article 19, which states that:

Progressive criminology advocates the use of non-institutional over institutional treatment. Little or no difference has been found in terms of the success of institutionalisation as compared to noninstitutionalisation. The many adverse influences on an individual that seem unavoidable within any institutional setting evidently cannot be outbalanced by treatment efforts. This is especially the case for juveniles, who are vulnerable to negative influences. Moreover, the negative effects, not only of loss of liberty but also of separation from the usual social environment, are certainly more acute for juveniles than for adults because of their early stage of development.

In view of the above, it makes sense that early release of child offenders is desirable. If one considers that young offenders who reach the age of 18 are soon thereafter transferred to an adult facility, and (it can be argued) exposed to increased negative influences, an argument for early conditional release gains further weight, if the rehabilitation and reintegration of child offenders into society is kept in mind. The fact that the UN has identified the prevention of juvenile delinquency as one of the most important aims of the implementation of the CRC and a core element of a comprehensive juvenile justice policy of any states party ${ }^{28}$ makes the argument even stronger. The CRC requires states to develop and implement such a comprehensive juvenile justice policy, which is to encompass all relevant articles of the CRC. ${ }^{29}$

It is noteworthy that the Committee on the Rights of the Child has gone even further and recommended that all forms of life imprisonment for offences committed by persons under the age of 18 should be abolished. This is because the likelihood that life imprisonment of a child will make it very difficult, if not impossible, to achieve the aims of juvenile justice despite the possibility of release. ${ }^{30}$ Article 79 of the JDLs provides further that all juveniles 
should benefit from arrangements designed to assist them in returning to society, family life, education, or employment after release. Procedures, including early release, and special courses should be devised to this end.

\section{Conclusion}

Having considered the provisions of international law instruments relating to the imprisonment and parole of child offenders, in addition to the relevant principles contained in South African law, one can easily come to the conclusion that South Africa treats child offenders (as far as parole is concerned) in a less favourable manner than is desirable.

The deprivation of liberty as a measure of last resort and for the shortest period of time means that state parties should have a welltrained functionary in place which can make maximum and effective use of measures such as, inter alia, the possibility of early release from detention. ${ }^{31}$ Furthermore, in cases of severe offences by children, the need to safeguard the well-being and the best interests of the child and to promote his reintegration must always outweigh the need for public safety and sanctions. ${ }^{32}$ This reintegration aim is also envisaged by article 40 of the CRC. In fact, the Committee on the Rights of the child has recognised that the aim of preservation of public safety is best served by a full respect for and implementation of the overarching principles of juvenile justice as enshrined in the CRC. 33

South Africa, it has been noted, possesses a lack of qualified professional personnel available to aid child (and other) offenders with their rehabilitation and reintegration back into society. It has also been established that children have special developmental needs, and that certain benefits to children should not and do not automatically cease upon the reaching of 18 years of age. This and the fact that children who reach 18 years of age are soon thereafter transferred to adult facilities, presenting them with tangibly worse influences, favours decreased incarceration for such offenders in the form of accelerated parole consideration. The crime date criterion should guide such accelerated consideration.

Related to the above is the argument that children and adults should be treated differently when it comes to parole. Article 2(2)(a) of the Beijing Rules states that children may be dealt with for an 
offence in a manner different from adults. This further supports an argument for accelerated parole consideration for child offenders.

One should keep in mind that additional benefits to child offenders are not to be seen as characteristic of a juvenile justice system which 'slacks off' in the punishment of child offenders, but rather as belonging to a system which takes the aims of protection of the society as well as of rehabilitation and reintegration of such children seriously. 